\title{
Studi mutu pelayanan berdasarkan kepuasan pasien di Klinik Gigi dan Mulut RSUP Dr. Wahidin Sudirohusodo Makassar
}

\author{
A. St. Asmidar Anas,* Andi Zulkifli Abdullah** \\ * Bagian Oral Biologi Fakultas Kedokteran Gigi Universitas Hasanuddin \\ ** Jurusan Epidemiologi Fakultas Kesehatan Masyarakat Universitas Hasanuddin \\ Makassar, Indonesia
}

\begin{abstract}
The improvement of quality health service has become a national and global main issue in the health development. This is due to great demand of service in health organization to provide optimum service health. The effort of improving quality health service consists of health organization and health professionals. This study aimed to describe patient satisfaction of service quality of health professional in dental clinic of RSUP Dr. Wahidin Sudirohusodo Makassar. The samples of this descriptive survey study were patients of the hospital who fulfill criteria of inclusion. Intake of samples by purpose, and sample size was 85 people. Patient satisfaction was determined using RATER dimensions -reliability, assurance, tangible, empathy and responsiveness. Service quality, which was assessed based on average of percentage of patient answers, is considered good if satisfaction is $\geq$ $60 \%$ and bad if satisfaction is $\leq 60 \%$. The results show that the reliability, assurance, tangible, empathy, and responsiveness of health officer, are $82.4 \%$, $76.5 \%, 89.4 \%, 87.1 \%$, and $78.8 \%$ respectively. The study concludes that service quality of the dental clinic in 2007 was good.
\end{abstract}

Key word: service quality, reliability, assurance, tangible, empathy, responsiveness

\begin{abstract}
ABSTRAK
Peningkatan kualitas layanan kesehatan menjadi isu utama dalam pembangunan bidang kesehatan, baik dalam lingkup nasional maupun global. Hal ini didorong oleh semakin besarnya tuntutan terhadap organisasi pelayanan kesehatan untuk memberikan layanan kesehatan secara prima. Upaya peningkatan kualitas layanan kesehatan meliputi kualitas organisasi pelayanan kesehatan dan tenaga profesional. Penelitian ini bertujuan untuk memperoleh gambaran kepuasan pasien terhadap mutu layanan petugas kesehatan di klinik gigi dan mulut RSUP Dr. Wahidin Sudirohusodo Makassar. Sampel penelitian survei deskriptif ini adalah pengunjung klinik gigi dan mulut rumah sakit tersebut yang memenuhi kriteria inklusi. Pengambilan sampel secara purposive, dan besar sampel 85 orang. Kepuasan pasien dinilai dengan dimensi RATER, yaitu reliability, assurance, tangible, empathy, dan responsiveness, dan mutu layanan dinilai berdasarkan rerata persentase jawaban pasien, yaitu baik, bila yang menyatakan puas $\geq 60 \%$, dan tidak baik $\leq 60 \%$. Hasil penelitian menunjukkan bahwa responden yang menjawab puas berdasarkan reliability, assurance, tangible, empathy, dan responsiveness masing-masing 82,4\%, 76,5\%, 89,4\%, 87,1\%, dan 78,8\%. Hasil Penelitian menyimpulkan bahwa mutu layanan klinik gigi pada tahun 2007 adalah baik.

Kata kunci: mutu layanan,reliability, assurance,tangible,empathy, responsiveness
\end{abstract}

Koresponden: A.St.Asmidar Anas, Bagian Oral Biologi Fakultas Kedokteran Gigi Universitas Hasanuddin, Jl. Perintis Kemerdekaan Km.10, Makassar,Indonesia. 


\section{PENDAHULUAN}

Kepuasan pasien merupakan salah satu hal sangat penting dalam mengevaluasi mutu layanan suatu rumah sakit. Ada empat aspek mutu yang dapat dipakai sebagai indikator penilaian mutu pelayanan suatu rumah sakit, yaitu tampilan keprofesian yang ada di rumah sakit (aspek klinis), efisiensi dan efektivitas penyelenggaraan layanan berdasarkan pemakaian sumber daya, aspek keselamatan, keamanan dan kenyamanan pasien, aspek kepuasan pasien yang dilayani. ${ }^{1}$

Saat ini masalah ketidakpuasan terjadi di negara berkembang maupun di negara maju. Ada berbagai macam pengertian yang diberikan oleh pakar tentang kepuasan. Kepuasan adalah tingkat perasaan seseorang setelah membandingkan kinerja/hasil yang dirasakan dengan harapannya. Kepuasan dapat diartikan sebagai perbedaan antara harapan dan kinerja yang dirasakan. ${ }^{2}$

Kepuasan pasien merupakan hal yang sangat subyektif, sulit diukur, dapat berubah-ubah, serta terdapat banyak sekali faktor yang berpengaruh; sebanyak dimensi di dalam kehidupan manusia. Subyektivitas tersebut bisa berkurang dan bahkan bisa menjadi obyektif bila cukup banyak pendapat yang sama terhadap sesuatu hal. Oleh karena itu, untuk mengkaji kepuasan pasien dipergunakan suatu instrumen penelitian yang cukup valid disertai dengan metode penelitian yang baik. ${ }^{1}$

Merkurious dkk, menyebutkan bahwa mengukur kepuasan pasien dapat digunakan sebagai alat untuk evaluasi kualitas layanan kesehatan, evaluasi terhadap konsultasi intervensi dan hubungan antara perilaku sehat dan sakit, membuat keputusan administrasi, evaluasi efek dari perubahan organisasi pelayanan, administrasi staf, fungsi pemasaran, dan formasi etik kedokteran. $^{3}$
Menurut Parasuraman dkk, ada lima dimensi yang digunakan oleh pelanggan dalam menilai kualitas layanan yaitu tampilan fisik (tangible), yang meliputi fasilitas fisik, perlengkapan pegawai dan sarana komunikasi; kehandalan (reliability), yakni kemampuan memberikan layanan yang dijanjikan dengan segera, akurat dan memuaskan; ketanggapan (responsiveness), yaitu keinginan para staf untuk membantu para pelanggan dengan cara memberikan layanan dengan tanggap; kepastian jaminan (assurance), yang mencakup pengetahuan, kemampuan, kesopanan dan sifat dapat dipercaya yang dimiliki para staf, bebas dari bahaya, risiko dan keraguraguan; dan kemampupahaman (empathy), yang meliputi kemudahan dalam melakukan hubungan, komunikasi yang baik, perhatian pribadi dan memahami kebutuhan para pelanggan. Kualitas layanan kesehatan lebih terkait pada kelancaran komunikasi. $^{4}$

Ada dua dimensi kepuasan pasien, yaitu dimensi pertama adalah kepuasan yang mengacu hanya pada penerapan standar dan kode etik profesi yang meliputi hubungan dokter-pasien, kenyamanan layanan, kebebasan menentukan pilihan, pengetahuan dan kompetensi teknis, efektivitas layanan dan keamanan tindakan. Dimensi kedua adalah kepuasan yang mengacu pada penerapan semua persyaratan layanan kesehatan, yang meliputi ketersedian, kewajaran, keterjangkauan, efisiensi dan mutu layanan kesehatan. $^{5}$

Rumah sakit merupakan suatu organisasi yang unik dan kompleks, oleh karena terdapat suatu usaha atau proses di bidang jasa, khususnya jasa medik dalam bentuk layanan kesehatan kepada penderita berupa rawat inap, rawat jalan, maupun penunjang medik. Selain itu rumah sakit merupakan organisasi padat karya yang di dalamnya terdapat berbagai disiplin ilmu yang 
berbeda-beda serta berhadapan langsung dengan orang-orang dengan emosi labil dan ketegangan emosional sementara mencari pertolongan. Olehnya itu pelayanan rumah sakit jauh lebih kompleks daripada tempat-tempat layanan lainnya. $^{6}$

Keluhan masyarakat sering terjadi oleh karena layanan yang kurang memuaskan, tingginya biaya layanan kesehatan, sarana dan prasarana kesehatan masih sangat terbatas serta faktor-faktor lain yang mempengaruhi kepuasan pasien terhadap layanan yang diberikan oleh pihak rumah sakit. Seiring dengan kemajuan teknologi di bidang kedokteran dan kesehatan, maka mutu layanan berkualitas harus pula ditingkatkan. Kepuasan pelanggan atau pasien adalah hal yang sangat penting yang tidak bisa diabaikan oleh para penentu kebijakan di bidang kesehatan. $^{7}$

Rumah Sakit Umum Pusat Dr. Wahidin Sudirohusodo (RSUPWS) di Makassar merupakan rumah sakit tipe A yang memberikan layanan spesialistik luas dan subspesialistik, termasuk layanan kesehatan gigi dan mulut. Selain menjadi rumah sakit rujukan di Indonesia Timur, RSUPWS juga merupakan rumah sakit penyelenggara pendidikan tenaga medis sehingga memungkinkan untuk melakukan beberapa penelitian yang berkaitan dengan masalah kesehatan termasuk mutu pelayanan petugas kesehatan itu sendiri.

Pada makalah ini akan dipaparkan hasil penelitian mengenai studi mutu pelayanan berdasarkan kepuasan pasien di klinik gigi dan mulut RSUP Dr. Wahidin Sudirohusodo Makassar yang bertujuan untuk memperoleh gambaran kepuasan pasien terhadap mutu layanan petugas kesehatan di klinik gigi dan mulut tersebut.

\section{BAHAN DAN METODE}

Penelitian ini bersifat survei deskriptif untuk mendapatkan gambaran kepuasan pasien terhadap mutu layanan berdasarkan dimensi RATER, yaitu reliability, assurance, tangible, empathy, dan reliability petugas kesehatan. Penelitian dilaksanakan di poliklinik gigi dan mulut RSUPWS, Makassar pada tahun 2007. Berdasarkan angka kunjungan bulanan sepanjang tahun 2006 diperoleh rerata kunjungan setiap bulan sebesar 600 orang. Dengan menggunakan rumus Slovin diperoleh jumlah sampel sebesar 85 orang. Pengambilan sampel dilakukan secara purposive sampling dengan kriteria inklusi, yaitu menerima perawatan lebih dari sekali kunjungan, berumur minimal 15 tahun, dan dapat berkomunikasi dan bersedia menjadi responden.

Mutu layanan adalah merujuk pada tingkat kesempurnaan layanan kesehatan, yang satu pihak menimbulkan kepuasan pada setiap pasien sesuai dengan tingkat kepuasan rata-rata penduduk, dan di lain pihak tata cara penyelenggaraannya sesuai dengan standar kode etik dan standar pelayanan profesi yang telah ditetapkan. ${ }^{8}$

Instrumen penilaian mutu pelayanan berdasarkan reliability, assurance, tangible, empathy, dan Responsiveness. Reliability merupakan persepsi pasien terhadap kemampuan menyajikan layanan secara konsisten, akurat sesuai yang dijanjikan. Indikatornya adalah petugas kesehatan selalu ada, melakukan tindakan tepat waktu, kecepatan diagnosis, memberikan informasi yang akurat terhadap pasien, serta memberi layanan dengan tidak membeda-bedakan pasien. Kriteria obyekatif adalah puas diberi skor 3, kurang puas diberi skor 2, dan tidak puas diberi skor 1 . Skor tertinggi adalah $6 \times 3=18$, sementara skor terendah $6 \times 1=6$. 
Assurance merupakan persepsi terhadap pengetahuan, kesopanan petugas serta dapat dipercaya sehingga pasien merasa mendapatkan jaminan kepastian layanan yang aman dan terpercaya. Indikatornya adalah petugas terampil dalam melakukan tindakan medik, menjawab pertanyaan pasien mengenai penyakitnya, teliti memberi obat, memberikan penjelasan yang akurat berkaitan dengan tindakan yang dilakukan. Kriteria obyektif adalah puas diberi skor 3, kurang puas diberi skor 2, dan tidak puas diberi skor 1 . Skor tertinggi adalah $6 \times 3=18$, sementara skor terendah $6 \times 1=6$.

Tangible merupakan persepsi pasien terhadap komponen berwujud dalam memberikan layanan kepada pasien. Indikatornya adalah fasilitas fisik rumah sakit, tampilan dokter dan paramedis, perlengkapan yang tersedia untuk pelayanan kepada pasien. Kriteria obyektifnya adalah puas diberi skor 3, kurang puas diberi skor 2, dan tidak puas diberi skor 1 . Skor tertinggi adalah $6 \times 3=18$, sementara skor terendah $6 \times 1=6$.

Empathy merupakan persepsi pasien terhadap petugas yang dinilai berdasarkan kemampuan dokter gigi dan perawat dalam memahami apa yang dirasakan pasien, dan menempatkan diri pada keadaan yang dihadapi atau yang dialami pasien, memperlakukan pasien dengan baik, dan selalu berada di tempat apabila pasien membutuhkan. Kriteria obyektifnya adalah jika puas diberi skor 3, kurang puas diberi skor 2, dan jika tidak puas diberi skor 1. Skor tertinggi adalah $6 \times 3=18$, sementara skor terendah $6 \times 1=6$.

Responsiveness merupakan persepsi pasien terhadap dokter dan perawat yang dinilai berdasarkan kecepatan tanggap dalam menolong pasien, serta dalam mengatasi masalah yang dihadapi oleh pasien. Kriteria obyektifnya adalah puas diberi skor 3, kurang puas diberi skor 2, tidak puas diberi skor 1 . Skor tertinggi adalah $6 \times 3=18$, sementara skor terendah $6 \times 1=6$.

Berdasarkan dimensi RATER tersebut, mutu pelayanan dinilai dengan indikator baik apabila jawaban responden yang menyatakan puas $\geq 60 \%$, dan tidak baik apabila jawaban responden yang menyatakan puas $<60 \%$.

\section{HASIL PENELITIAN}

Tabel 1 menunjukkan bahwa distribusi responden menurut pekerjaan yang terbanyak pada PNS/TNI-Polri/Pensiunan sebesar 35 responden dan yang paling sedikit adalah wiraswasta sebesar 4 responden. Sementara distribusi responden menurut pendidikan yang terbanyak adalah perguruan tinggi sebanyak 56 responden dan tingkat pendidikan yang paling sedikit adalah tidak sekolah dan SMP, masing-masing 1 responden. Jenis kelamin responden terbanyak adalah perempuan sebesar $58,8 \%$. Sedangkan menurut cara pembayaran pasien, terbanyak ditanggung oleh PT. Askes sebesar 55 responden dan yang paling sedikit adalah JPS Gakin sebesar 4 responden.

Pada tabel 2 terlihat bahwa sebagian besar responden menyatakan puas dengan reliability petugas kesehatan, yaitu sebesar $82,4 \%$, dan tidak ada yang menyatakan tidak puas. Tanggapan responden terhadap assurance, terlihat 76,5\% yang merasa puas atas jaminan dan kepastian yang diberikan petugas kesehatan. Sementara pada penilaian responden terhadap tangible petugas kesehatan, $89,4 \%$ responden merasa puas, dan sisanya merasa tidak puas. Tanggapan terhadap empathy petugas kesehatan, 87,1\% responden merasa puas. Sedangkan penilaian responden terhadap responsiveness petugas menunjukkan bahwa $78,8 \%$ menyatakan puas. 
Tabel 1. Distribusi responden berdasarkan karakteristik pekerjaan, pendidikan, jenis kelamin dan cara pembayaran pasien di poli gigi dan mulut RSUPWS Makassar pada tahun 2007.

\begin{tabular}{|c|c|c|}
\hline Karakteristik responden & $\mathrm{n}$ & $\%$ \\
\hline \multicolumn{3}{|l|}{ Pekerjaan } \\
\hline 1. PNS/TNI-POLRI/Pensiunan & 35 & 41,2 \\
\hline 2. Wiraswata & 4 & 4,7 \\
\hline 3. Pelajar/mahasiswa & 25 & 29,4 \\
\hline 4. Ibu RT & 9 & 10,6 \\
\hline \multirow[t]{2}{*}{ 5. Lain-lain } & 12 & 14,1 \\
\hline & 85 & 100 \\
\hline
\end{tabular}

\section{Pendidikan}

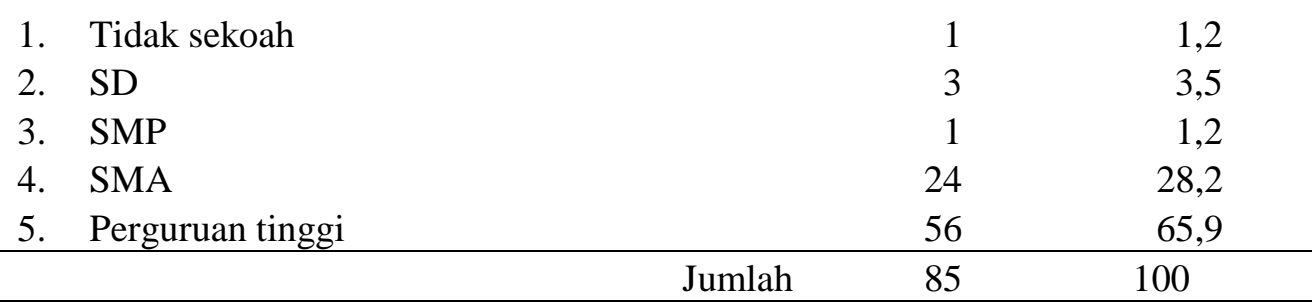

\begin{tabular}{llcc}
\hline Jenis Kelamin & & \\
1. Laki-laki & 35 & 41,2 \\
2. Perempuan & 50 & 58,8 \\
\hline & & 55 & 100 \\
\hline
\end{tabular}

\begin{tabular}{llrc}
\hline Cara pembayaran pasien & & \\
1. Umum & 26 & 30,6 \\
2. Askes & 55 & 64,7 \\
3. JPS Gakin & 4 & 4,7 \\
\hline & & 85 & 100 \\
\hline
\end{tabular}

Sumber: data primer

Tabel 2. Tanggapan responden terhadap mutu layanan petugas kesehatan berdasarkan dimensi RATER di poli gigi dan mulut RSUPWS Makassar pada tahun 2007.

\begin{tabular}{ccccccccccc}
\hline \multirow{2}{*}{$\begin{array}{c}\text { Tanggapan } \\
\text { Responden }\end{array}$} & Reliability & Assurance & Tangible & Empathy & \multicolumn{2}{c}{ Responsiveness } \\
\cline { 2 - 12 } & $\mathrm{n}$ & $\%$ & $\mathrm{n}$ & $\%$ & $\mathrm{~N}$ & $\%$ & $\mathrm{n}$ & $\%$ & $\mathrm{n}$ & $\%$ \\
\hline Puas & 70 & 82,4 & 65 & 76,5 & 76 & 89,4 & 74 & 87,1 & 67 & 78,8 \\
Kurang puas & 15 & 17,6 & 20 & 23,5 & 9 & 10,6 & 10 & 11,7 & 18 & 21,2 \\
Tidak puas & 0 & 0 & 0 & 0 & 0 & 0 & 1 & 1,2 & 0 & 0 \\
Jumlah & 85 & 100 & 85 & 100 & 85 & 100 & 85 & 100 & 85 & 100 \\
\hline
\end{tabular}

Sumber: data primer

\section{PEMBAHASAN}

Berdasarkan pendidikan, mayoritas responden adalah perguruan tinggi yaitu 56 orang atau 65,9\%. Pendidikan responden sangat mempengaruhi persepsi mereka tentang mutu layanan, karena persepsi mengenai mutu layanan dipengaruhi oleh tingkat pendidikan yang dapat diketahui melalui jenjang pendidikan seseorang. 
Sementara itu, pekerjaan responden berhubungan dengan pendidikannya, yaitu pada penelitian ini ditemukan mayoritas pekerjaan responden adalah Pegawai Negeri Sipil/TNIPOLRI/Pensiunan yaitu sebesar 35 orang atau $41,2 \%$. Sedangkan berdasarkan cara pembayaran pasien terlihat bahwa pasien Askes mendominasi kunjungan di poli gigi RSUPWS Makassar yaitu sebesar 55 orang $(64,7 \%)$. Hal ini bisa dipahami karena rumah sakit ini melayani rujukan pelayanan kesehatan gigi dari puskesmas.

Reliability yang dimaksud di sini adalah kemampuan menyajikan pelayanan secara konsisten, akurat sesuai yang dijanjikan. Reliability meliputi kemampuan memberi informasi tentang pelayanan kesehatan yang akan diberikan. Dalam pelayanan kesehatan gigi dan mulut di poli gigi RSUPWS Makassar, reliability petugas merupakan kemampuan petugas baik dokter maupun perawat dalam melakukan tindakan tepat waktu, memberikan informasi yang dibutuhkan dan tidak bersikap diskriminatif terhadap pasien.

Ketanggapan petugas kesehatan dalam melayani pasien di poli gigi RSUPWS Makassar umumnya baik, yaitu 70 responden $(82,4 \%)$ responden menyatakan puas, dan hanya $17,6 \%$ yang tidak puas. Dalam hal ini mutu layanan ditinjau dari cara pandang pelanggan lebih terkait pada dimensi ketanggapan petugas dalam memenuhi kebutuhan pasien serta memberikan informasi yang dibutuhkan. Hal ini menyebabkan antara persepsi pasien dengan kenyataan yang diterima tidak besar kesenjangannya.

Hal tersebut di atas sesuai dengan pendapat Parasuraman, ${ }^{4}$ yaitu bahwa kualitas layanan yang dipersepsikan oleh pelanggan didefinisikan sebagai seberapa besar kesenjangan antara persepsi pelanggan atau kenyataan layanan yang diterima dibandingkan dengan harapan pelanggan atas layanan yang diterima.

Assurance atau jaminan dan kepastian adalah pengetahuan atau wawasan, kesopansantunan, kepercayaan diri dari pemberi layanan kesehatan serta respek terhadap pelanggan. Di poli gigi RSUPWS Makassar, assurance adalah kemampuan petugas, baik dokter maupun perawat yang terampil dan cekatan sehingga memberi rasa aman terhadap pasien, ketelitian dalam memberi pengobatan serta penjelasan atas setiap tindakan medik yang diberikan kepada pasien.

Menurut Parasuraman dkk, ada beberapa faktor yang mempengaruhi assurance yaitu competence yaitu ilmu pengetahuan dan keahlian yang dibutuhkan untuk memberikan layanan, courtessy yaitu kesopan-santunan yang meliputi sikap sopan santun, respek, perhatian dan keramahan individu yang langsung berhubungan dengan pelanggan, serta credibility yaitu kepercayaan, kejujuran dan reputasi yang dimiliki oleh rumah sakit. ${ }^{4}$

Dari hasil penelitian, diperoleh 76,.5\% responden merasa puas atas jaminan dan kepastian yang diberikan petugas kesehatan dan yang menyatakan kurang puas sebanyak 23,5\% responden. Jaminan atau kepastian yang dinilai adalah berdasarkan tanggapan pasien secara pribadi bukan berdasarkan jaminan kepastian pengobatan dari segi medis. Seorang pasien melihat petugas baik dokter maupun perawat mampu memberikan jaminan jika mereka terampil dan cekatan dalam menggunakan peralatan, teliti memberikan pengobatan dan mampu memberi penjelasan terhadap tindakan medik yang dilakukan.

Tangible adalah layanan secara fisik, meliputi fasilitas fisik rumah sakit, tampilan dokter dan paramedis, dan perlengkapan yang tersedia untuk pelayanan kepada pasien. Dalam penelitian ini, 
tangible adalah kemampuan petugas kesehatan baik dokter maupun perawat poli gigi RSUPWS Makassar dalam melayani pasien, meliputi tampilan fisik yang selalu bersih dan rapih, sikap yang selalu ramah dalam menghadapi pasien serta kesopanan terhadap pasien.

Berdasarkan hasil penelitian diketahui bahwa 76 responden $(89,4 \%)$ merasa puas atas penampilan dan sikap dokter dan perawat. Hal ini berarti bahwa mutu pelayanan dianggap baik ditinjau dari segi penampilan fisiknya. Meskipun demikian, masih ada $10,6 \%$ responden yang merasa kurang puas sehingga penampilan dan sikap petugas perlu ditingkatkan.

Empathy yang dimaksud di sini adalah kemampuan petugas dalam memahami dan menempatkan diri pada keadaan yang dihadapi atau yang dialami oleh pasien melalui respon emosional, mengerti sepenuhnya tentang kondisi dan perasaan pasien dan mampu melakukan komunikasi yang baik dalam memahami kebutuhan pasien.

Mutu layanan ditinjau dari pengguna lebih terkait pada dimensi ketanggapan petugas memenuhi kebutuhan pasien, kelancaran komunikasi petugas dengan pasien, keprihatinan, serta keramahtamahan petugas dalam melayani dan atau kesembuhan penyakit yang sedang diderita oleh pasien. $^{8}$

Sikap dan perilaku dokter, perawat dan petugas lain di rumah sakit tinggi peringkatnya dalam kepuasan pasien. Walau hasil akhir (outcome) layanan kurang sesuai dengan harapan pasien, pasien masih dapat memahaminya dan tetap dapat merasakan kepuasannya, karena dilayani dengan sikap dan perilaku yang menghargai perasaan dan martabatnya. ${ }^{1}$

Berdasarkan hasil penelitian ini diperoleh data bahwa 74 responden $(87,1 \%)$ merasa puas atas empati petugas kesehatan. Hal ini berarti mutu pelayanan kesehatan dianggap baik karena mayoritas pasien merasa puas atas empati yang diberikan petugas kesehatan. Penilaian ini berdasarkan persepsi pasien terhadap petugas kesehatan dalam memberikan layanan senantiasa bersikap sabar, telaten, memperlakukan pasien dengan baik serta memiliki rasa hormat, bersahabat dan selalu menanyakan perkembangan pasien. Meskipun demikian, perlu ditingkatkan empati petugas terhadap pasien karena masih ada $11,7 \%$ responden yang merasa kurang puas dan $1,2 \%$ yang tidak puas.

Responsiveness atau daya tanggap yang dimaksud di sini adalah kemampuan atau kecepattanggapan petugas dalam memberi layanan dan pengobatan terhadap pasien. Di poli gigi RSUPWS Makassar, responsiveness petugas baik dokter maupun perawat diukur dari bagaimana petugas mau mendengarkan keluh-kesah pasien, segera datang bila dipanggil, menawarkan bantuan baik diminta maupun tidak diminta oleh pasien.

Berdasarkan hasil penelitian ini diperoleh informasi bahwa $78,8 \%$ responden merasa puas dan menilai petugas poli gigi tanggap atas keluhan dan kebutuhan mereka. Ini berarti dari segi responsiveness petugas kesehatan, mutu pelayanan dianggap baik. Namun perlu ditingkatkan karena terdapat 18 responden yang merasa kurang puas atas daya tanggap petugas kesehatan. Hal ini mungkin disebabkan karena panjang jam pelayanan di poli gigi yang diselingi waktu istirahat bagi petugas kesehatan (ishoma).

Ketanggapan petugas merupakan hakekat dasar mutu layanan kesehatan dalam memenuhi kebutuhan dan tuntutan para pemakai jasa layanan kesehatan yang apabila berhasil dipenuhi akan dapat menimbulkan rasa puas terhadap layanan kesehatan yang diselenggarakan. ${ }^{8}$ 


\section{SIMPULAN}

Berdasarkan hasil penelitian dan pembahasan tentang mutu pelayanan berdasarkan kepuasan pasien di poliklinik gigi dan mulut RSUP Dr. Wahidin Sudirohusodo dapat disimpulkan bahwa berdasarkan reliability petugas kesehatan secara umum dinilai baik, yaitu 70 responden $(82,4 \%)$ merasa puas dan 15 responden $(17,6 \%)$ merasa kurang puas. Berdasarkan assurance, petugas kesehatan secara umum dinilai baik, yaitu 65 responden $(76,5 \%)$ merasa puas dan 20 responden $(23,5 \%)$ merasa kurang puas. Berdasarkan tangible petugas kesehatan secara umum dinilai baik, yaitu 76 responden $(89,54 \%)$ merasa puas, dan hanya 9 responden $(10,6 \%)$ merasa kurang puas. Sedangkan berdasarkan empathy petugas kesehatan secara umum juga dinilai baik, yaitu 74 responden $(87,1 \%)$ merasa puas, 10 responden $(11,7 \%)$ merasa kurang puas, dan hanya 1 responden $(1,2 \%)$ tidak puas. Dimensi terakhir, berdasarkan responsiveness, petugas kesehatan secara umum juga dinilai baik, yakni 67 responden $(78,8 \%)$ merasa puas dan hanya 18 responden $(21,2 \%)$ merasa kurang puas.

\section{SARAN}

Berdasarkan hasil yang diperoleh dan simpulan, disarankan kepada pihak RSUP Dr. Wahidin Sudirohusodo Makassar untuk terus berupaya meningkatkan sarana dan prasana fisik rumah sakit serta kualitas petugas kesehatan sehingga dapat memberikan layanan prima kepada pengguna sesuai dengan yang diharapkan demi menjawab tantangan globalisasi bidang kesehatan khususnya dalam pelayanan kesehatan.

\section{DAFTAR PUSTAKA}

1. Suryawati C. Kepuasan pasien rumah sakit (tinjauan teoritis dan penerapannya pada penelitian). J Manajemen Pelayanan Kesehatan 2004; 7(4).

2. Suprapto. Pengukuran tingkat kepuasan pelanggan untuk menaikkan pangsa pasar. Jakarta: Rineka Cipta; 2001.

3. Merkuoris A, Lanara V, Ifabtopoulos, Lemonidou C. Patien satisfaction: A key concept for evaluating and improving nursing practice. J Nursing Management 1999.

4. Parasuraman A, Zethami VA, Berry LI. A conceptual model of service quality and its implications for future research. 1990

5. Krowinski WJ, Steven RS. Measuring and managing patient satisfaction. American Hospital Publishing Inc.; 1996.

6. Ansar J. Mutu pelayanan kesehatan RSUD Salewangang Kabupaten Maros tahun 2006. Makalah tidak dipublikasi. Konsentrasi Epidemiologi Program Pascasarjana Unhas; 2007.

7. Wijono D. Manajemen mutu pelayanan kesehatan: Teori, strategi dan aplikasi, Vol. 2. Surabaya: Airlangga University Press; 1999.

8. Azwar A. Manajemen mutu pelayanan kesehatan. Jakarta: Pustaka Sinar Utama; 1996. 